\title{
RECURRENT PROPERTY TAXES IN COMMUNAL BUDGETS - IDENTIFICATION OF TYPES OF COMMUNES AND THEIR SPATIAL DIFFERENTIATION
}

\author{
Maria Trojanek, Prof. \\ Department of Investment and Real Estate \\ Poznań University of Economics and Business \\ e-mail:mariatrojanek@wp.pl \\ Wojciech Kisiała, PhD \\ Department of Spatial and Environmental Economics \\ Poznan University of Economics and Business \\ e-mail:wojciech.kisiala@ue.poznan.pl
}

\begin{abstract}
The main aim of this paper is to identify differences between Polish communes as regards their revenues from property taxes. To this end, we distinguished and described types of communes with similar configurations of features under analysis (incomes from real property tax, agricultural tax and forest tax). In the research procedure, we applied methods of multidimensional analysis, with particular emphasis on cluster analysis. The research was conducted on the basis of aggregated (to eliminate random fluctuations) values of income from properties in the years 2013-2015. On the basis of typological classification, we distinguished six clusters (groups) of communes of different quantitative characteristics of budget revenues from property taxes. We identified specific regularities in the distribution of the distinguished commune types.
\end{abstract}

Key words: recurrent property taxes, commune types, cluster analysis, $k$-means method, Poland.

JEL Classification: $C 38, H 71, H 72, R 39$.

Citation: Trojanek M., Kisiała W., 2018, Recurrent Property Taxes in Communal Budgets - Identification of Types of Communes and their Spatial Differentiation, Real Estate Management and Valuation, vol. 26, no. 1, pp. 39-50.

DOI: $10.2478 /$ remav-2018-0004

\section{Introduction}

Each commune has its distinct natural and socioeconomic features, which may represent resources that determine its development potential. These resources include properties which may be used for generating one-time income (sale) and regular income flows (taxes, rents), and for carrying out investment projects and creating reserves for achieving development goals in the future. Differences in the potential of communes as regards property management are reflected in the financial state of their budgets and in the condition of local economies.

Property taxation and government and public agency charges in the real estate market are a significant determinant of the investment attractiveness of areas and of local development. Not only are taxes and charges a source of income to local budgets, they also stimulate the inflow of external capital and new investments. That is why tax policy is an important instrument of the policy of social 
and economic development of local government units pursued by local authorities (DZIEMIANOWICZ 1998; MARKOWSKI 1999; THEDY et al. 2007; ŹRÓBEK et al. 2016).

A large part of the budget revenue of a commune is directly or indirectly connected with real estate management. Properties located in the area of a commune, both those which are a part of municipal property and ones belonging to other entities, constitute the statutory source of income for communes. Revenues obtained by communes from real estate management come from different sources and are of a varied character. The existing body of literature provides a number of classifications of these revenues (BORODO 2004; BORODO 2011; PATRZAŁEK 2004; DYLEWSKI et al. 2006; RUŚKOWSKI, SAŁACHNA 2007; Łaguna 2002; MisZCZuK 2009; CyMeran 2009; CZEMPas 2010; FARVACQUe-VitKovic, Kopanyi 2014; MORGAN et al. 2015; GŁUSZAK, MARONA 2015; CYMERMAN, ZAPOTOCZNA 2016).

Among all public rents in the real estate sector, a special role is attributed to a group of taxes referred to as recurrent property taxes. They include property rights connected with ownership, not involving any business event or administrative-legal procedure. By principle, it is the owner of a property who is a taxpayer in this case, but in most countries the tax obligation is also imposed on autonomous and dependent possessors (tenants, lessees). A set of such taxes is called the system of real estate taxation sensu stricto. It does not include taxes and charges on real estate transactions, income taxes or taxes related to an increase in the value of a property (GŁUSZAK, MARONA 2015; ŹRÓBEK et al. 2016; CYMERMAN, ZAPOTOCZNA 2016).

The system of real estate taxation in Poland consists of three property taxes: a real property tax, an agricultural tax and a forest tax. Among them, it is the real property tax that holds the primary role, since it provides the largest revenue for local budgets. The tax is calculated on the basis of the size of land and of the floor space of buildings and flats. Land that is covered by the agricultural or forest tax is not subject to the real property tax unless it is used for activities other than agricultural or forestrelated ones.

The aim of this paper is to examine the differences between communes in Poland as regards the structure of budget revenue from real estate taxation. On the basis of the identified values of incomes from real property, agricultural and forest taxes, we devised a typology of communes, distinguishing and describing groups of similar configurations. Additionally, we identified the spatial differentiation of the specified types of communes.

In the empirical part of the study, we used data obtained from the Regional Accounting Chamber (Polish: Regionalna Izba Obrachunkowa) in Bydgoszcz. The study was conducted on the basis of aggregated (in order to eliminate incidental variations) values of incomes of communes in Poland in the years 2013-2015 in relation to population size.

\section{Tax incomes from real estate}

\subsection{Real property tax}

In Poland, just like in other countries of Central and Eastern Europe, as well as in France and the United Kingdom (MISZCZUK 2009; SWIANIEWICZ 2011), property tax is the basic local tax - it is of fundamental importance for the budgets of communes, being the source of their income. Real property tax is usually calculated on the basis of the value of a property defined as the market value, rental value, or - much less often - the size of land and buildings.

In some countries, different bases for calculating real property tax are used at the same time. The criteria for determining the taxable base may be as follows:

- location (e.g. Western Australia, where rental value is the base for calculating tax in cities, while the market value of non-built-up land is used in the countryside);

- type of use (e.g. in the United Kingdom, residential properties are taxed on the basis of market value, while commercial properties on the basis of rental value);

- development or lack of development (e.g. Ivory Coast - developed properties are taxed on the basis of their rental value, while undeveloped properties on the basis of market value);

- right to property (MCCLUSKEY et al. 2013).

In Poland, the tax is based on: for land - its size; for buildings or their parts connected with running a business activity - their value, established on 1 January of the tax year, constituting the basis of calculating depreciation in that year, not reduced by depreciation allowances. If no depreciation was recorded on the buildings or their parts, the market value determined by the taxpayer is the taxable base. Tax rates for a given tax year are established by way of resolution of the 
commune council, but cannot exceed the maximum statutory rates updated annually by the Minister of Finance as announced in the Official Gazette of the Republic of Poland "Monitor Polski".

The commune council is obliged to establish real property tax rates. Commune councils may vary rates (Act of 12 January 1991, Art. 5, par. 2) for the specific types of taxable subjects, taking into consideration:

1) location,

2) land use,

3) type of development,

4) type of activity.

The upper brackets of real property tax change every year depending on the inflation rate.

The legislator (Art. 7 of the quoted Act on local taxes and charges - Act of 12 January 1991) provided for objective and subjective tax exemptions. Objective exemptions concern the following types of properties:

1) buildings constituting a part of railway infrastructure and the land they occupy, if the infrastructure administrator is obliged to make it available to licensed domestic carriers,

2) land and buildings which remained after railway lines or their sections were closed - until their ownership or right to perpetual usufruct is transferred - no later than three years from the first day of the month following the month in which the decision became final,

3) buildings of port infrastructure, buildings of infrastructure providing access to sea ports and harbors, and the land they occupy,

4) buildings and the land they occupy in the area of some public use airports,

5) others, listed in the quoted Article 7.

As far as subjective exemptions are concerned, the legislator provided for the exemptions of the following subjects:

1) universities (except for taxable items used for business activity),

2) schools, teachers' training institutions and organs running these institutions on account of the administration, use, and perpetual usufruct of school real properties,

3) research units of the Polish Academy of Sciences,

4) entities running supported employment enterprises,

5) research and development units,

6) entrepreneurs with the status of a research and development center with reference to taxable items used for research and development activity.

Additionally, apart from the exemptions specified in the Act on local taxes and charges, there are also exemptions stipulated in other acts. These include:

1) exemptions and reliefs for church legal entities, who are owners or users of properties occupied for non-residential purposes and, at the same time, are not used for business activity,

2) exemptions granted on account of running a business activity in special economic zones,

3) exemptions concerning land and buildings being part of properties intended for building public roads acquired by the State Treasury or local government.

There is the ceiling of rates that communes are not allowed to exceed and most communes use maximum rates or rates close to the upper limit. Thus, irrespective of the location, standard, technical condition and other important features of a property, tax charges in a given commune are the same. It also does not matter whether the building is new and in an attractive location, or a building in bad technical condition located on the outskirts of town.

Under the existing law, although commune councils can vary tax rates, they rarely do. This is because it is difficult to create a fair system of differentiating tax rates. The real property tax rate in Poland is not linked, whatsoever, with the value of the taxable item (the value of a property). This fact provides an argument for the introduction of ad valorem tax, which has been advocated since the beginning of the transformation of the system in Poland.

\subsection{Agricultural tax}

Communes obtain income from agricultural tax under the Act on agricultural tax (Act of 15 November 1984). Under Art. 1 of this act, land designated as agricultural land or as wooded or bushy land that is a part of agricultural land is subject to agricultural tax, with the exception of the land used for business activities other than connected with agriculture. 
The taxable base is: for land of agricultural farms - the number of conversion hectares established on the basis of the area, types and classes of agricultural land as recorded in the land and property register and depending on the tax district; for other land - the number of hectares as recorded in the land and property register.

The number of conversion hectares depends on:

1) the size of the farm,

2) the type and class of agricultural land,

3) the tax district that a commune where the farm is located belongs to.

A conversion hectare is an approximate measure of the average profitability of one hectare in a given area. The land use value for establishing agricultural tax is represented by conversion coefficients shown in Table 1.

Table 1

Conversion rates of the size of agricultural land

\begin{tabular}{ccccccccc}
\hline Type of land & \multicolumn{3}{c}{ Arable land } & \multicolumn{5}{c}{ Meadows and pastures } \\
\hline Tax districts & I & II & III & IV & I & II & III & IV \\
\hline Agricultural land classes & & \multicolumn{7}{c}{ Conversion rates } \\
\hline I & 1.95 & 1.80 & 1.65 & 1.45 & 1.75 & 1.60 & 1.45 & 1.35 \\
\hline II & 1.80 & 1.65 & 1.50 & 1.35 & 1.45 & 1.35 & 1.25 & 1.10 \\
\hline IIIa & 1.65 & 1.50 & 1.40 & 1.25 & & & & \\
\hline III & & & & & 1.25 & 1.15 & 1.05 & 0.95 \\
\hline IIIb & 1.35 & 1.25 & 1.15 & 1.00 & & & & \\
\hline IVa & 1.10 & 1.00 & 0.90 & 0.80 & & & & \\
\hline IV & & & & & 0.75 & 0.70 & 0.60 & 0.55 \\
\hline IVb & 0.80 & 0.75 & 0.65 & 0.60 & & & & \\
\hline V & 0.35 & 0.30 & 0.25 & 0.20 & 0.20 & 0.20 & 0.15 & 0.15 \\
\hline VI & 0.20 & 0.15 & 0.10 & 0.05 & 0.15 & 0.15 & 0.10 & 0.05 \\
\hline
\end{tabular}

Source: (Act of 15 November 1984).

The agricultural tax for a tax year is: from one conversion hectare of the land of agricultural farms the money equivalent of 2.5 quintals of rye; from one hectare of other land - the money equivalent of 5 quintals of rye calculated based on the average price of rye for the first three quarters of the preceding year. The average price of rye is established on the basis of the announcement of the Chairman of the Main Statistical Office. Art. 12 par. 1 of the act lists the types of agricultural land statutorily exempted from tax (objective exemptions), including class V, VI agricultural land and wooded and bushy land being part of agricultural land, land located in the border strip, arable land, meadows and pastures covered by land reclamation - in the year in which crops were damaged as a result of drainage works, and ecological land. Art. 12.2 of the act provides for subjective exemptions. The act specifies the following four kinds of tax reliefs:

1) investment relief - it amounts to $25 \%$ of capital investment (documented by receipts) in building or modernizing buildings designated for environmental protection,

2) soldiers' relief - this relief amounts to $60 \%$ of the tax rate if the owner of the farm serves in the army or takes part in long-term military training; it is $40 \%$ of the rate if a member of the farm owner's family serves in the army,

3) mountain relief - owners of farms located in piedmont or mountainous areas are entitled to this relief (it refers to farms located more than 350 meters above sea level); the agricultural tax on the land in these areas is reduced by $30 \%$ to $60 \%$ depending on the valuation class of land,

4) relief on account of natural disasters - this relief is applied in the case of natural disasters if they caused damage to buildings, crops, livestock, or stands of trees. 


\subsection{Forest tax}

Communes obtain revenues from forest tax under the Act on forest tax (Act of 30 October 2002). Forests specified in the act are subject to this tax, with the exemption of forests used for purposes other than forestry.

Forest tax payers include natural persons, legal entities, and organizational entities without legal personality, which are the owners of forests, the autonomous possessors of forests or perpetual usufructuaries of forests belonging to the State Treasury or a local government unit. The taxable base is the area of forest, expressed in hectares, as recorded in the land and property register. The forest tax for one hectare in a tax year amounts to the money equivalent of 0.220 cubic meters of wood, calculated as the average price of wood obtained by the Forest District in the first three quarters of the year preceding the tax year (Art. 4 par. 1 of the act on forest tax). The average selling price of wood, referred to in par. 1, is determined on the basis of the announcement of the Chairman of the Main Statistical Office. A commune council may, by way of resolution, reduce the amount of the average selling price of wood adopted as the base for the determining the forest tax rate in the area of the commune. Art. 7 par. 1 provides for the following objective tax exemptions:

1) forest stand under 40 years old,

2) forests individually inscribed in the register of monuments,

3) ecological sites.

Art. 7 par. 2 specifies objective and subjective exemptions. A commune council may, by way of resolution, introduce other objective exemptions, regarding specific types of tree stand.

\subsection{Data and Methods}

In the research procedure aimed at distinguishing commune types on the basis of revenues from local real property taxes, we used cluster analysis, which is one of the methods of multidimensional clustering (BAILEY 1994). In cluster analysis, the examined group of objects is divided into homogenous subsets (groups, clusters) on the basis of the similarity of diagnostic variables characteristic of particular objects. The principles of division depend on the adopted method. In our study, we used the non-hierarchical clustering method of k-means. It is an iterative-optimizing method, in which the number of clusters (groups) and the number of iterative improvement procedures are established a priori. Objects are moved from one cluster to another until the configuration of clusters which meets the preset optimization criterion (usually, it is the minimization of the so-called clustering squared errors) is obtained. The optimization algorithm is completed when the expected number of iterations has been reached or if no objects have been moved between clusters in a given phase (MACQUEEN 1967; ALDENDERFER, BLASHFIELD 1984; EVERITT et al. 2011; PANEK, ZWIERZCHOWSKI 2013; JAWORSKA, MODRANKA 2014; TVARONAVICIENE et al., 2015; REIFF et al., 2016).

In all multidimensional comparative analyses, what is of key importance to the obtained results is the selection of features describing the complexity of the examined phenomena. In order to compare communes in terms of budget revenues from real property taxes, we used the classification of public income according to articles of income as specified in the Regulation of the Minister of Finance concerning the detailed classification of incomes, expenditures, revenues and expenses, and funds from foreign resources. We used data from the annual reports on the execution of the plan of budget revenues $\mathrm{Rb}$-27S (executed revenues) obtained from the Regional Accounting Chamber (Polish: Regionalna Izba Obrachunkowa) in Bydgoszcz.

In the procedure of clustering with the use of the k-means method, the diagnostic variables were the amounts of revenue from three categories of the property tax system in Poland (see: TROJANEK 2015):

1) real property tax (Article 031),

2) agricultural tax (Article 032),

3) forest tax (Article 033).

In order to eliminate the problem of random fluctuations resulting from incidental influences, the study was conducted on the basis of data covering aggregate values from the years 2013-2015. Additionally, the obtained amounts were relativized by referring them to the population size of particular communes.

In the next steps of the research procedure, the diagnostic variables became subject to transformation and formal-statistical verification, in accordance with the criteria described in, among 
other, the works of PARYSEK and WOJTASIEWICZ (1979), GRABIŃSKI (1991), PANEK and ZWIERZCHOWSKI (2013), and JAWORSKA and MODRANKA (2014). As a result, the clustering of k-means was conducted with a set of standardized variables of a stimulating nature significantly discriminating the examined units (communes) and having no strong causal-effect relationships.

The procedure of grouping communes according to the level of various types of income from property taxation was conducted with the assumed division of the examined set into six clusters (types of communes) and with the expected maximum number of iterations optimizing the configuration of groups amounting to 10 . The centroids of preliminary clusters were determined randomly - by sorting distances and selecting observations at a constant interval. The clustering was conducted with the application of the STATISTICA software package.

\section{Empirical results}

Following the application of k-means method, we singled out six types (clusters) of communes with different parameters characterizing local budget revenues from property taxes. When interpreting the results, one must remember that the diagnostic variables used in the study were subject to the standardization procedure. This is why their arithmetic means are zero; negative values refer to objects (communes) with lower than average revenue from real estate, while positive values refer to objects (communes) with revenues higher than the group average.

The typology of communes, prepared on the basis of tax revenue generated by real estate (Articles 31,32 and 33) showed that, among the six clusters distinguished, three were singled out because of extremely high amounts of real property (TI-5), agricultural (TI-6) and forestry (TI-4) taxes. Another two types included communes of the lowest revenue from the analyzed taxes: real property tax - type TI-1, and agricultural and forest tax - type TI-2. Type TI-3, in turn, referred to those communes where revenue from property taxation was relatively average, with considerably higher income from forest tax, see: Table 2 and Figure 1).

Table 2

The characteristics of commune types distinguished according to budget revenue from property taxes

\begin{tabular}{ccccc}
\hline \multirow{2}{*}{ Type } & $\begin{array}{c}\text { Number of } \\
\text { Communes }\end{array}$ & \multicolumn{4}{c}{$\begin{array}{c}\text { Average values of budget revenues in the years 2013-2015 per capita } \\
\text { (in brackets standard value means): }\end{array}$} \\
\cline { 3 - 5 } & & $\begin{array}{c}\text { Real Property Tax } \\
\text { (Article 31) }\end{array}$ & $\begin{array}{c}\text { Agricultural Tax } \\
\text { (Article 32) }\end{array}$ & $\begin{array}{c}\text { Forest Tax } \\
\text { (Article 33) }\end{array}$ \\
\hline TI-1 & 723 & $895.78(-0.22)$ & $399.97(0.50)$ & $29.29(-0.17)$ \\
\hline TI-2 & 1249 & $1312.01(0.03)$ & $99.58(-0.66)$ & $19.70(-0.32)$ \\
\hline TI-3 & 247 & $1228.55(-0.02)$ & $248.07(-0.09)$ & $136.05(1.51)$ \\
\hline TI-4 & 27 & $1706.77(0.27)$ & $216.24(-0.21)$ & $438.67(6.27)$ \\
\hline TI-5 & 28 & $9731.19(5.08)$ & $145.02(-0.48)$ & $61.82(0.34)$ \\
\hline TI-6 & 204 & $1015.90(-0.14)$ & $912.54(2.46)$ & $33.70(-0.10)$ \\
\hline & 2478 & $1257.31(0.00)$ & $270.74(0.00)$ & $40.28(0.00)$ \\
\hline
\end{tabular}

Source: Own study based on data obtained from the Regional Accounting Chamber (Polish: Regionalna Izba Obrachunkowa) in Bydgoszcz.

Type TI-1, characterized by high income from agricultural tax, the lowest income from real property tax, and relatively low income from forest tax, was mainly identified in the central and eastern part of Poland and in Lower Silesia and Pomerania (723 communes in total). Communes classified as type TI-2 were characterized by average values of real property tax and extremely low income from agricultural and forest tax. 1,249 communes of this type include the biggest Polish cities and their surrounding areas. They are mostly located in central (Greater Poland, Masovian and Łódź Provinces, and, to a lesser extent, Kuyavian-Pomeranian Province) and southern Poland (Silesian, Lesser Poland and Świętokrzyskie Provinces, a large part of Opole and Subcarpathian provinces, communes of the Sudety Mountains in Lower Silesia province, and a significant area of Pomeranian province, including Kashubian communes). A distinct feature of communes belonging to type TI-3 
(247 communes) was relatively high revenue from forest tax with relatively average values of real property and agricultural tax. This type prevailed in Lubusz Province and in Central Pomerania. Type TI-3 communes were also identified in the southern part of Warmian-Masurian Province and were scattered in Podlaskie Province. Type TI-4 was distinguished on account of extremely high revenues from forest tax, accompanied by high revenue from real property tax and relatively low income from agricultural tax. This cluster includes only 27 communes with exceptionally large woodland areas and intensive forest management (border communes in Podlaskie Province, communes in the Bieszczady Mountains, and some communes in Lubusz and Pomeranian Provinces). What characterized type TI-5 communes was extremely high revenue from real property tax, along with higher than average income from forest tax and very low income from agricultural tax. Twenty-eight communes of this cluster include industrial communes with rich natural resources (e.g. Kleszczów, Kleczew, Polkowice, Bogatynia or Jerzmanowa), transit communes (such as Stryków, Kobierzyce or Terespol), and tourism oriented ones (e.g. Darłowo, Karpacz, Solina, Rewal, Ustronie Morskie and Krynica Morska). Finally, type TI-6 was characterized by extremely high revenue from agricultural tax, relatively low income from real property tax, and extremely low income from forest tax. This group consists mainly of rural communes from the northern part of Warmian-Masurian Province, the central and eastern part of Lower Silesian Province, the eastern part of Lublin Province and the south of Podlaskie Province. Communes of this type are also scattered in West Pomeranian, KuyavianPomeranian and Opole Provinces.

Among the six distinguished clusters, it is type TI-4 that is the most distinct, which is reflected in extremely high Euclidean distances between the centroid of this group and those of the others (see: Table 3). Distances between group centroids also show that TI-5 stands out from the rest (although to a smaller degree than the TI-5 group). Thus, groups with relatively low income from real property tax show similarities. This may imply a right-skewed distribution of income from real property - the significant majority of communes are characterized by budget revenue from real property tax lower than the arithmetic mean for all communes, and only a small number of communes obtain revenue that considerably exceeds the average level. This observation was confirmed by the calculated skewness coefficients, which had positive values for each of the examined variables (arithmetic means were much higher than medians).

Table 3

Distances between clusters (groups)

\begin{tabular}{ccccccc}
\hline Group & TI-1 & TI-2 & TI-3 & TI-4 & TI-5 & TI-6 \\
\hline TI-1 & 0.000000 & 0.685432 & 1.033063 & 3.752595 & 3.122632 & 1.135231 \\
\hline TI-2 & 0.685432 & 0.000000 & 1.107447 & 3.818272 & 2.939772 & 1.805609 \\
\hline TI-3 & 1.033063 & 1.107447 & 0.000000 & 2.755741 & 3.026802 & 1.740831 \\
\hline TI-4 & 3.752595 & 3.818272 & 2.755741 & 0.00000 & 4.41126 & 3.99633 \\
\hline TI-5 & 3.122632 & 2.939772 & 3.026802 & 4.41126 & 0.00000 & 3.46994 \\
\hline TI-6 & 1.135231 & 1.805609 & 1.740831 & 3.99633 & 3.46994 & 0.00000 \\
\hline
\end{tabular}

Source: Own study based on data obtained from the Regional Accounting Chamber (Polish: Regionalna Izba Obrachunkowa) in Bydgoszcz.

Similarities were also observed between the TI-1 cluster, and TI-3 and TI-6 clusters. Thus, they concerned the groups containing communes with relatively low income from real property.

The analysis of variance, which estimates the discriminative strength of particular variables, shows that it was income from agricultural tax that played the decisive role in the division into clusters (see: Table 4). The value of the F-statistic for this variable considerably exceeded the values calculated for the other two variables (income from forest tax and real property tax). All the variables, however, contributed statistically significantly to the final classification $(p<0.000)$.

The analysis of the distribution of communes belonging to a particular type (Fig. 1) shows that they form clusters of specific spatial configurations. Type TI-2 communes are located mainly in central and southern Poland, while those belonging to type TI-3 and TI-4 are found in the northern, western and 
eastern parts of the country. Types TI- 1 and TI-5 are observed throughout the entire country, while type TI-6 mainly includes communes located in the north, north-west and east of Poland.

Table 4

The results of single factor variance analyses

\begin{tabular}{lcccccr}
\hline Variable & $\begin{array}{c}\text { Inter-cluster } \\
\text { variance } \\
\text { (sum of } \\
\text { squares) }\end{array}$ & $\begin{array}{c}\text { Degrees } \\
\text { of } \\
\text { freedom }\end{array}$ & $\begin{array}{c}\text { Inner-cluster } \\
\text { variance } \\
\text { (sum of } \\
\text { squares) }\end{array}$ & $\begin{array}{c}\text { Degrees } \\
\text { of } \\
\text { freedom }\end{array}$ & F & $\begin{array}{c}\mathrm{p} \\
\text { significance }\end{array}$ \\
\hline real property tax & 763.667 & 5 & 1713.333 & 2472 & 220.364 & 0.000 \\
\hline agricultural tax & 1957.195 & 5 & 519.805 & 2472 & 1861.537 & 0.000 \\
\hline forest tax & 1780.731 & 5 & 696.269 & 2472 & 1264.444 & 0.000 \\
\hline
\end{tabular}

Source: Own study based on data obtained from the Regional Accounting Chamber (Polish:

Regionalna Izba Obrachunkowa) in Bydgoszcz.

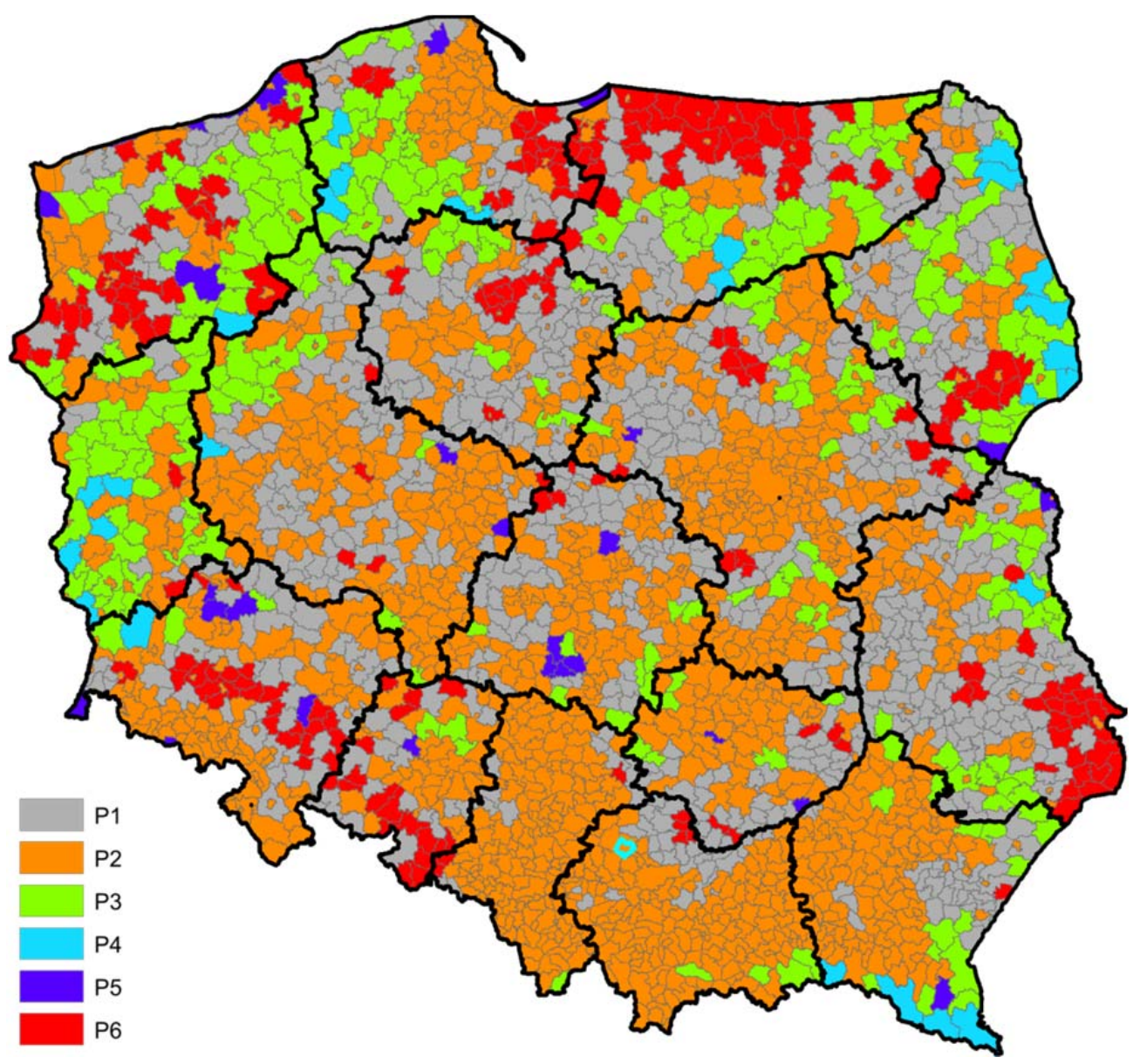

Fig. 1. The spatial differentiation of commune types distinguished according to budget revenue from property taxes (Articles 31, 32 and 33). Source: own study.

Type TI-2 prevailed in 10 Polish provinces (Lowe Silesian, Łódź, Lesser Poland, Masovian, Opole, Subcarpathian, Pomeranian, Silesian, Świętokrzyskie and Greater Poland). In four provinces (Kuyavian-Pomeranian, Lublin, Podlaskie and Warmian-Masurian), communes belonging to type TI-1 accounted for the largest share, while in one province (Lubusz) type TI-3 was dominant. In West Pomeranian Province, communes of type TI-2, TI-3 and TI- 6 represented an equal share (almost $25 \%$ ). It is worth drawing attention to the fact that the high percentage of type TI- 6 communes is found in Opole and Warmian-Masurian Provinces, and those of type TI-3 - in Podlaskie, Pomeranian and 
Warmian-Masurian provinces. Communes of type TI-4 accounted for the largest share in Lubusz and Podlaskie Provinces, and type TI-5 ones in West Pomeranian and Lower Silesian Provinces (see: Table 5).

Table 5

Percentage of communes representing a given type (group) in Poland

\begin{tabular}{lcccccc}
\hline Province & Type N1 & Type N2 & Type N3 & Type N4 & Type N5 & Type N6 \\
\hline Lower Silesia & 26.6 & 52.1 & 1.8 & 0.6 & 3.6 & 15.4 \\
\hline Kuyavian-Pomeranian & 47.9 & 35.4 & 7.6 & 0.0 & 0.0 & 9.0 \\
\hline Lublin & 49.8 & 27.2 & 10.3 & 0.5 & 0.5 & 11.7 \\
\hline Lubusz & 11.0 & 39.0 & 41.5 & 6.1 & 0.0 & 2.4 \\
\hline Łódź & 39.0 & 50.8 & 5.1 & 0.0 & 2.8 & 2.3 \\
\hline Lesser Poland & 14.3 & 81.3 & 2.2 & 0.0 & 0.0 & 2.2 \\
\hline Masovian & 33.1 & 54.8 & 7.3 & 0.0 & 0.3 & 4.5 \\
\hline Opole & 25.4 & 43.7 & 4.2 & 0.0 & 1.4 & 25.4 \\
\hline Subcarpathian & 18.8 & 68.1 & 9.4 & 2.5 & 0.6 & 0.6 \\
\hline Podlaskie & 40.7 & 23.7 & 22.9 & 5.9 & 0.8 & 5.9 \\
\hline Pomeranian & 19.5 & 40.7 & 19.5 & 4.1 & 1.6 & 14.6 \\
\hline Silesian & 6.6 & 91.0 & 0.6 & 0.0 & 0.0 & 1.8 \\
\hline Świętokrzyskie & 35.3 & 52.0 & 5.9 & 0.0 & 2.0 & 4.9 \\
\hline Warmian-Masurian & 27.6 & 25.0 & 19.0 & 1.7 & 0.0 & 26.7 \\
\hline Greater Poland & 32.3 & 57.5 & 6.6 & 0.4 & 0.9 & 2.2 \\
\hline West Pomeranian & 20.2 & 24.6 & 24.6 & 0.9 & 5.3 & 24.6 \\
\hline Poland & 29.2 & 50.4 & 10.0 & 1.1 & 1.1 & 8.2 \\
\hline
\end{tabular}

Source: Own study based on data obtained from the Regional Accounting Chamber (Polish: Regionalna Izba Obrachunkowa) in Bydgoszcz.

\section{Discussion and conclusions}

On the basis of our study, we distinguished six types of communes of different quantitative characteristics of budget revenues from property taxes (real property tax, agricultural tax and forest tax). We observed a right-skewed distribution of income, so there were relatively few communes representing a type with extremely high income from property taxes and similarities were evident in groups and between groups of low and very low levels of the analyzed revenues. What played a decisive role in the division of communes into groups was the income from agricultural tax, which is imposed on agricultural land, with the exception of the land used for business activities other than agricultural activities. Incomes from forest tax and real property tax had less influence on the final typology.

The obtained results show some spatial regularities in the distribution of communes belonging to particular groups (clusters). They result from the differentiation of the settlement structure in the particular parts of the country, their location and accessibility, and functional (predominant functions in particular communes) and economic factors (the level of investment, infrastructure, etc.). Also important are the historical factors, which are reflected in the differences in revenues from property taxes between the areas which were once under Russian, Prussian and Austrian rule, and the areas of the so-called Recovered Territories that became a part of Poland after World War Two.

Our study is part of broader research into budget revenues from real estate management in Poland (see, among others: GŁUSZAK, MARONA 2014; TROJANEK, KisIAŁA 2016; CYMERMAN, ZAPOTOCZNA 2016; 
KiSIAŁA, TROJANEK 2017) and other countries (see, among others: ROSENGARD 1998; BAHL, MARTINEZVAZQUEZ 2007; NORREGAARD 2013; BLAŽIć et al. 2016; ŹRÓBEK et al. 2016). What makes it valuable is the local scale of analysis, making it possible to recognize the role of the particular types of property taxes in local budgets. Thanks to identifying the characteristic features of the distinguished types of communes, which are often related to their administrative classification (rural, urban, urban-rural) and to their economic condition, local governments can actively influence the local real estate market and, consequently, obtain higher budget revenues.

The distribution of tax burdens in local property markets requires further in-depth studies. They are necessary to formulate and implement tax policy and select appropriate instruments that will guarantee the rationality and efficiency of research in the area of real estate management. This paper provides new arguments in the ongoing debate in literature and should be seen as a contribution to the explanation of differences between communes as regards their budget revenues related to real estate management.

\section{References}

AldENDERfER M.S., BlASHFIELD R.K., 1984, Cluster Analysis. Quantitative Applications in the Social Sciences, SAGE Publications, Beverly Hills.

Bahl R., Martinez-VAzQuez J., 2006, The Property Tax in Developing Cuntries: Current Practice and Prospects, International Studies Program Working Paper 06-37, Georgia State University.

BAILEY K.D., 1994, Typeologies and Taxonomies. An Introduction to Classification Techniques, Sage Publications, Thousand Oaks - London - New Delhi.

BlAŽıć H., ŠIMOVIĆ H., ŠTAMBUK A., 2016, Introduction of a Local Real Estate Tax in Croatia: a Survey of Expert and Public Opinion, Lex localis - Journal of Local Self-Government, Vol. 14, No. 1, pp. 53-74.

Borodo A., 2004, Samorząd terytorialny. System prawno-finansowy (Territorial Self-Government. Legal and Financial System), Lexis-Nexis, Warsaw.

BORODO A., 2011, System finansowy samorzadu terytorialnego w Polsce (Financial System of Territorial selfgovernment in Poland), Dom Organizatora TNOiK, Torun.

CYMerman J., 2009, System opłat od nieruchomości. Aspekty teoretyczne i prawne (Real Estate Fee System. Theoretical and Legal Aspects), Educaterra, Olsztyn.

CYMERMAN J., ZAPOTOCZNA M., 2016, System opodatkowania nieruchomości w Polsce na tle wybranych krajów (System of Real Estate Taxation in Poland Compared to Chosen States), Prace Naukowe Uniwersytetu Ekonomicznego we Wrocławiu, No. 433, pp. 40-52.

CZEMPAs J., 2010, Udziat podatku od nieruchomości w budżetach gmin województwa ślaskiego (Property Tax Share in Commune Budgets of Silesian Voivodeship), Wiadomości Statystyczne, No. 6, pp. 59-64.

DYLEWSKI M., FILIPIAK B., GORZAŁCZYŃSKA-KOCZKODAN M., 2006, Finanse samorządowe. Narzędzia. Decyzje. Procesy (Local Government Finance. Tools. Decisions. Processes), PAN, Warsaw.

DZIEMIANOWICZ W., 1998, Rola władz samorządowych w stymulowaniu naptywu bezpośrednich inwestycji zagranicznych (The Role of Local Governments in the Stimulation of the Inflow of Foreign Direct Investment), in: Bezpośrednie inwestycje zagraniczne (Foreign Direct Investment), ed. OLESIŃSKI Z., PWE, Warsaw.

EveritT B.S., LANDAU S., LEESE M., STAHL D., 2011, Cluster Analysis. 5th Edition, Wiley, Chichester.

FARVACQUE-VITKOVIC C.D., KOPANYI M., eds., 2014, Municipal Finances: A Handbook for Local Governments, The World Bank, Washington, D.C.

GŁuszaK M., Marona B., 2014, Property Tax and the Fiscal Independence of Polish Local Government, Actual Problems of Economics, 6(156), pp. 364-373.

GŁUSZAK M., MARONA B., 2015, Podatek katastralny. Ekonomiczne uwarunkowania reformy opodatkowania nieruchomości (Cadastral Tax. The Economic Determinants of the Reform of Property Taxation), Wydawnictwo Poltext, Warsaw.

GRABIŃSKI T., 1991, Podstawy informacyjne ekonometrii przestrzennej (The Information Bases of Spatial Econometrics), pp. 26-38, in: Ekonometria przestrzenna (Spatial Econometrics), ed. ZELIAŚ A., PWE, Warsaw.

JAWORSKA R., MODRANKA E., 2014, Metody opisowej statystyki przestrzennej oraz wybrane zagadnienia eksploracyjnej analizy danych przestrzennych (Methods of Descriptive Spatial Statistics and Selected Issues of Exploration of Spatial Data Analysis), pp. 111-144, in: Statystyka przestrzenna. Metody analiz struktur przestrzennych (Spatial Statistics Methods of Analysis of Spatial Structures), ed. SUCHECKA J., Wydawnictwo C.H.Beck, Warsaw. 
KisiąA W., TROJANEK M., 2017, Typologia gmin w Polsce na podstawie dochodów z nieruchomości (The Classification of Polish Municipalities According to Income from Real Estate), Acta Scientiarum Polonorum Administratio Locorum, Vol. 16, No. 2, pp. 77-85.

ŁAGUNA T.M., 2002, Aktywne gospodarowanie nieruchomościami szansa zwiększenia wpływów dla budżetów gmin (Active Real Estate Management as an Opportunity to Affect the Volume of Revenues to Municipal Budgets), in: Finanse publiczne w skali lokalnej (Public Finance on the Local Level), ed. ADAMOWICZ M., Wydawnictwo SGGW, Warsaw.

MACQuEEN J.B., 1967, Some Methods for Classification and Analysis of Multivariate Observations, Proceedings of the Fifth Berkley Symposium on Mathematical Statistics and Probability, vol. 1, University of California Press, Berkley, pp. 281-297.

MARKOWSKI T., 1999, Zarzadzanie rozwojem miast (Urban Development Management), Wydawnictwo Naukowe PWN, Warsaw.

MCCluskey W.J., CorniA G.C., Walters L.C., 2013, A Primer on Property Tax: Administration and Policy, John Wiley \& Sons, Oxford.

MiszCZUK M., 2009, System podatków i opłat samorządowych w Polsce (System of Local Government Taxes and Fees in Poland), Wydawnictwo C.H.Beck, Warsaw.

Morgan D., RobinSON K.S., StRACHOTA D., HougH J.A., 2015, Budgeting for Local Governments and Communities, Routledge Taylor \& Francis Group, London - New York.

NorregaARD J., 2013, Taxing Immovable Property Revenue Potential and Implementation Challenges, IMF Working Paper WP/13/129.

PANEK T., ZWIERZCHOWSKI J., 2013, Statystyczne metody wielowymiarowej analizy porównawczej. Teoria i zastosowania (Statistical Methods of Multidimensional Comparative Analysis. Theory and Application), Oficyna Wydawnicza SGH, Warsaw.

PARYSEK J.J., WOJTASIEWICZ L., 1979, Metody analizy regionalnej i metody planowania regionalnego (Methods of Regional Analysis and Methods of Regional Planning), Studia KPZK PAN, vol. LXIX, PWN, Warsaw.

PATRZAŁEK L., 2004, Finanse samorzadu terytorialnego (Finances of Territorial Self-government), Wydawnictwo Akademii Ekonomicznej we Wrocławiu, Wrocław.

Reiff, M., Surmanová, K., BalcerzaK, A. P., \& PietrzaK, M. B. (2016). Multiple Criteria Analysis of European Union Agriculture. Journal of International Studies, 9(3), pp. 62-74.

RosengARD J.K., 1998, Property Tax Reform in Developing Countries, Kluwer Academic Publishers, Norwell, Massachusetts.

Rozporządzenie Ministra Finansów z dnia 2 marca 2010 r. w sprawie szczegótowej klasyfikacji dochodów, wydatków, przychodów i rozchodów oraz środków pochodzących ze źródeł zagranicznych, Dziennik Ustaw z 2010, nr 38, poz. 207 z późniejszymi zmianami (The Minister of Finance's Regulation of 2 March 2010 on the Detailed Classification of Incomes, Expenses, Revenues and Expenditures, and Funds from Foreign Resources, Journal of Laws No. 38, item 207, as amended).

RUŚKOWSKI E., SAŁACHNA J.M., 2007, Finanse lokalne po akcesji (Local finance after accession), Wolters Kluwer Business, Warsaw.

SWIANIEWICZ P., 2011, Finanse samorząowe. Koncepcje, realizacja, polityki lokalne (Local Government Finances. Concepts, Implementation, Local Policies), Municipum, Warsaw.

THEDY M., KRASOWSKI T., WASILUK A., 2007, Opodatkowanie rynku nieruchomości (Property Market Taxation), Wydawnictwo C.H. Beck, Warsaw.

Tvaronaviciene, M., RazMiniene, K., \& PiccinetTi, L. (2015). Aproaches Towards Cluster Analysis. Economics \& Sociology, 8(1), pp. 19-29.

TROJANEK M., 2015, Gospodarowanie nieruchomościami w gminach w aspekcie ich dochodowości (Real Estate Management in Municipalities in Terms of their Profitability), Wydawnictwo Uniwersytetu Ekonomicznego w Poznaniu, Poznań.

TrojaneK M., KisiaŁA W., 2016, The Diversification of Communes' Revenue from Real Estate Across Provinces, Real Estate Management and Valuation, Vol. 24, No. 2, pp. 36-49.

Ustawa z dnia 12 stycznia 1991 r. o podatkach i opłatach lokalnych, Dz. U. 1991 nr 9 poz. 31, z późn. zm. (Act of 12 January 1991 on local taxes and charges, Journal of Laws, 1991, No. 9, item 31, as amended).

Ustawa z dnia 15 listopada 1984 r. o podatku rolnym, Dz. U. 1984 nr 52 poz. 268 z późn. zm. (Act of 15 November 1984 on agricultural tax, Journal of Laws, 1984, No. 52, item 1381, as amended). 
Ustawa z dnia 30 października 2002 r. o podatku leśnym, Dz. U. 2002 nr 200 poz. 1682, z późn. zm. (Act of 30 October 2002 on forest tax, Journal of Laws, 2002, No. 200, item 1682, as amended).

ŹRÓBEK S., MANZHYNSKI S., ZYSK E., RASSOKHAY., 2016, Some Aspects of Local Real Estate Taxes as an Instrument of Land Use Management, Real Estate Management and Valuation, Vol. 24, No. 3, pp. 93105. 